\title{
Sodium bicarbonate as prevention of metabolic acidosis in sheep submitted to experimental ruminal acidosis ${ }^{1}$
}

\author{
Luciane M. Laskoski²* Lívia S. Muraro ${ }^{3}$, Marinho S. Santana Júnior ${ }^{3}$, Mariana \\ B. Carvalho ${ }^{3}$, Silvio H. Freitas ${ }^{3}$, Renata G.S. Dória ${ }^{4}$, Marcelo D. Santos ${ }^{3}$ \\ and Rosangela Locatelli Dittrich ${ }^{2}$
}

\begin{abstract}
Laskoski L.M., Muraro L.S., Santana Júnior M.S., Carvalho M.B., Freitas S.H., Dória R.G.S., Santos M.D. \& Locatelli Dittrich R. 2014. Sodium bicarbonate as prevention of metabolic acidosis in sheep submitted to experimental ruminal acidosis. Pesquisa Veterinária Brasileira 34(9):822-826. Programa de Pós-Graduação em Ciências Veterinárias, Universidade Federal do Paraná, Campus Curitiba, Rua dos Funcionários 1540, Curitiba, PR 83035-050, Brazil. E-mail: luci.laskoski@gmail.com

The aim of this study was to evaluate the preventive effect of sodium bicarbonate on systemic acidosis due to ruminal acidosis, which was induced by ingestion of concentrate after prolonged fasting. Fourteen sheep were divided into three experimental groups: control group $(\mathrm{Cg})$, with four sheep, submitted to fasting without development of ruminal acidosis; no-treated group (NTg), with five sheep with rumen acidosis without preventive treatment; and treated group ( $\mathrm{Tg}$ ), with five sheep with rumen acidosis and preventively treated with sodium bicarbonate. Assessments of ruminal $\mathrm{pH}$ and arterial hemogasometry were performed for 48 hours after ingestion of the concentrate. There was a reduction in the ruminal $\mathrm{pH}$ in all groups, whereas the Cg showed a reduction only after 24 hours. A reduction in the arterial $\mathrm{pH}$, bicarbonate and base excess in all groups was also noted, indicating systemic metabolic acidosis, but the NTg presented the greatest alteration. It is concluded that sodium bicarbonate prevents systemic metabolic acidosis, reducing its severity in sheep subjected to ruminal acidosis.
\end{abstract}

INDEX TERMS: Sodium bicarbonate, lactic ruminal acidosis, systemic metabolic acidosis, buffering, hemogasometry, sheep.

RESUMO.- [Bicarbonato de sódio como preventivo da acidose metabólica em ovinos submetidos à acidose ruminal experimental.] 0 objetivo deste estudo foi avaliar o efeito preventivo do bicarbonato de sódio sobre a acidose sistêmica em decorrência da acidose ruminal, a qual foi induzida pelo fornecimento de concentrado após jejum prolongado. Foram utilizados 14 ovinos, divididos em três grupos experimentais: grupo controle $(\mathrm{Cg})$, contendo quatro

\footnotetext{
${ }^{1}$ Received on June 20, 2014.

Accepted for publication on July 15, 2014.

${ }^{2}$ Programa de Pós-Graduação em Ciências Veterinária, Universidade Federal do Paraná (UFPR), Curitiba, PR 83035-050, Brazil. E-mails: roslocdi@ufpr.br; *Correspondig author: luci.laskoski@gmail.com

${ }^{3}$ Programa de Pós-Graduação em Biociência Animal, Universidade de Cuiabá, Cuiabá, MT 70000-001, Brazil. E-mails: liviatcho@hotmail.com, marinhojunior_16@hotmail.com, mamabueno_carvalho@hotmail.comm silviof@krotoniuni.com.br, marcelo.diniz@kroton.com.br

${ }^{4}$ Faculdade de Zootecnia e Engenharia de Alimentos (FZEA), Universidade de São Paulo, Pirassununga, SP 13635-900, Brazil. E-mail: redoria@usp.br
}

ovinos, submetidos a jejum sem desenvolvimento de acidose ruminal; grupo não tratado (NTg), contendo cinco ovinos submetidos a acidose ruminal sem tratamento preventivo; e grupo tratado ( $\mathrm{Tg}$ ), contendo cinco ovinos, submetidos a acidose ruminal e tratados preventivamente com bicarbonato de sódio. Foram realizadas avaliações do $\mathrm{pH}$ ruminal e hemogasometria arterial, durante 48 horas após o fornecimento do concentrado. Houve redução do $\mathrm{pH}$ ruminal em todos os grupos, sendo que o $\mathrm{Cg}$ apresentou a redução apenas às 24 horas. Notou-se redução do $\mathrm{pH}$ arterial, bicarbonato e excesso de base em todos os grupos, indicando acidose metabólica sistêmica; no entanto, o NTg apresentou o quadro mais grave. Conclui-se que o bicarbonato de sódio possui efeito preventivo da acidose metabólica sistêmica, reduzindo a sua gravidade em ovinos submetidos à acidose ruminal.

TERMOS DE INDEXAÇÃO: Bicarbonato de sódio, acidose láctica ruminal, acidose metabólica sistêmica, tamponantes, hemogasometria, ovelhas. 


\section{INTRODUCTION}

Systemic metabolic acidosis is characterized by reduced concentrations of bicarbonate in the blood, either by the reduced ion excretion or increased use as acid buffer (Lahiriet al. 1981, Sobiech et al. 2005). A major cause of metabolic acidosis in ruminants is the ruminal acidosis, which affects dairy and beef cattle, sheep and goats (Patra et al. 1993). Ruminal lactic acidosis occurs because of the fast degradation of substances rich in carbohydrates (Slyter 1976), normally supplied as grains in excess, leading to an imbalance in the proportion of bacteria able to metabolize lactate, such as Megasphaera elsdenii, Selenomonas ruminantum and Veillonella alcalescens, and an increased number of producing bacteria, such as Streptococcus Bovis and Lactobacillus spp. (Miranda Neto et al. 2005). The degradation of carbohydrates produces lactic acid that is absorbed and reduces the blood $\mathrm{pH}$, which can be fatal (Ortolani 2003). The damage of the $\mathrm{pH}$ reduction to the ruminal mucosa allows fluid from the bloodstream to enter the rumen, causing severe dehydration (Aschenbach \& Gabel 2000), worsening metabolic acidosis (Braun et al. 1992).

The ruminant animal has a complex system of acid-base regulation. Increasing levels of dietary fiber can increase the buffering capacity of the rumen due to the stimulation of saliva production (Kohn \& Dunlop 1998). However, in situations requiring high levels of concentrates, such as intensive animal farming, these adjustments are more difficult to be made, and the use of $\mathrm{pH}$ buffer additives becomes necessary (Erdman 1988).

Sodium bicarbonate (NaHCO3) is a weak base that buffers the hydrogen ions (Ha et al. 1983) and is used in ruminant diets to increase ruminal pH (Kezar \& Church 1979). In order to balance the ratios of bacteria, the ruminal $\mathrm{pH}$ should be above 5.5 (Nagaraja \& Taylor 1987). Kezar \& Church (1979) claim that sodium bicarbonate provided in the diet increases ruminal $\mathrm{pH}$ and prevents the damage of the rumen epithelium caused by rumen lactic acidosis. However, these results differ in literature and current buffer researches seek to identify the largest voluntary intake by animals suffering from acute or subacute ruminal acidosis (Erdeman 1988, Phy \& Provenza 1998, Cottee et al. 2004), since it has been very effective on the treatment of acute ruminal lactic acidosis (Oliveira et al. 2009, Aslan et al. 1995), when the disease has already occurred. Despite being largely used as a preventive, the buffering effects are being researched in combination with other substances, such as magnesium oxide (Golder et al. 2014).

Whereas high productivity in ruminants is linked to high carbohydrate intake, which results in increased incidence of ruminal lactic acidosis, the aim of this study was to evaluate the effectiveness of sodium bicarbonate in the prevention of metabolic acidosis in sheep undergoing experimental rumen acidosis, through the supply of concentrate after prolonged fasting.

\section{MATERIALS AND METHODS}

The study was approved by the Research Ethics Committee (Comitê de Ética em Pesquisa - CEP/UNIC), register number 156, protocol 2010-153.
Animals. We used 14 crossbred Santa Inês sheep, 2-3 years old and weighing 28-34 kilograms, not pregnant and vermifuged. The animals received coast cross hay and a commercial concentrate for sheep. In order to collect samples of rumen fluid, ruminal cannulae were implanted. The animals were randomly divided into three groups: control group (Cg), with four animals, fasted for 48 hours, without induction of ruminal lactic acidosis; no-treated group (NTg), with five animals, fasted for 48 hours and with induction of ruminal lactic acidosis without treatment; treated group (Tg), with five animals, fasted for 48 hours, with induction of ruminal lactic acidosis and preventively treated with sodium bicarbonate.

Implantation of ruminal cannula. The procedure was performed with animals fasted for 24 hours, sedated with xylazine $2 \%$, infiltrative local anesthesia with lidocaine (left abdominal wall) and fixation of the cannula on the rumen wall (Reichert Neto 1996). After the procedure, the animals were treated with enrofloxacin $(5 \mathrm{mg} / \mathrm{kg}$, SID) for seven days, flunixin meglumine $(1.1 \mathrm{mg} / \mathrm{kg}$, SID) for three days and the wound was daily cleaned until complete healing.

Diet. After the healing of the implanted rumen cannula, the animals received forage, about 600 grams per animal per day for two weeks. Subsequently, the animals went through a gradual rumen adaptation to the concentrate, in a total period of 15 days, until the maximum amount of 600 grams per animal per day, divided into two meals, was reached. The animals in the treated group received 60 grams of sodium bicarbonate per animal per day $(1 \%$ of the dry matter), supplied with the concentrate. The adaptation to the concentrate, with or without sodium bicarbonate was performed 30 days prior to the induction of ruminal lactic acidosis.

Induction of ruminal lactic acidosis. The ruminal acidosis was induced in sheep of the treated (Tg) and no-treated (NTg) experimental groups through the ingestion of concentrate after a period of 48 hours fasting with no water restriction. The amount of concentrate supplied to the induction was the same as used on a daily meal of 300 grams per animal. In the treated group, we used the same amount of concentrate with the addition of 30 grams of sodium bicarbonate per animal. The food was provided for oral intake and administered via rumen cannula, as needed, not exceeding the 10-minute intake time for all animals. After this period, animals received forage ad libitum until the end of the observation (48 hours).

The control sheep were not induced to rumen lactic acidosis. They fasted for 48 hours and after this period, they received forage ad libitum. After the last evaluation (48 hours), animals were treated with replacement of rumen fauna (transfaunation) by administering rumen contents of fistulated sheep, not used in this study.

Samples collection. Samples of ruminal fluid and arterial blood of animals from all groups were collected in nine different times: basal (before fasting); time zero (after fasting and before the supply of food), 4 hours, 8 hours, 12 hours, 16 hours, 24 hours, 36 hours and 48 hours after food intake.

Ruminal pH. Samples of ruminal fluid were collected by means of a surgical aspirator inserted via ruminal fistula, and the $\mathrm{pH}$ of the contents was evaluated by a bench $\mathrm{pH}$ meter (Quimis, Q400MT).

Hemogasometry. The blood for hemogasometric evaluation was collected of the auricular artery, through a puncture and heparinized capillary tubes, which were immediately inserted into the hemogasometer (Roche, Cobas B 121). Blood pH, base excess (BE), and bicarbonate were analyzed.

Statistics. The Shapiro Wilk test was applied to assess the normality pattern of results. The results of ruminal $\mathrm{pH}$, plasma 
bicarbonate and base excess were within normal limits, making it possible to use the analysis of variance - ANOVA, and evaluation of means by Fisher's exact test. For the arterial pH, parametric result, we performed the assessment with the Kruskal Wallis test between groups and between times; and to compare means, we also used the Fisher's exact test, considering $\mathrm{p}<0.05$ for all.

\section{RESULTS}

\section{Inspection of animals}

The animals of the NTg and Tg groups presented depression, appetite loss with reduction of rumination at 8 hours after ingestion of the concentrate, remaining until the end of the experimental period. Three animals had diarrhea, one of the Tg and two of the NTg. There were no changes in the $\mathrm{Cg}$ animals.

\section{Ruminal pH}

After fasting for 48 hours, there was an increase in the ruminal $\mathrm{pH}$ of the $\mathrm{Cg}$ and $\mathrm{NTg}$, when compared to the $\mathrm{Tg}$. Four hours after food intake, the NTg returned to the basal value, but the Cg maintained its high values, which only reduced to the basal value at eight hours. Moreover, at this time, there was a reduction in the ruminal $\mathrm{pH}$ of the $\mathrm{NTg}$ and $\mathrm{Tg}$ groups, with no difference between them, remaining below the Cg until 16 hours. At 24 hours, the NTg had a lower $\mathrm{pH}$ than the $\mathrm{Cg}$. In the moments 36 and 48 hours, the values of the Tg and NTg groups did not differ from the $\mathrm{Cg}$, and from the basal value of each group (Fig.1).

\section{Hemogasometry}

The NTg had its arterial blood pH decreased at eight hours after ingestion of the concentrate when related to time zero. However, the reduction was below the Tg only after twelve hours, remaining below until the end of the eva- luations. The most critical moment was at 36 hours, with a $\mathrm{pH}$ reduction in all groups, and the lowest value was in the NTg, with a mean of 7.26, indicating metabolic acidosis. With exception of this time, the Cg did not differ from the other groups (Fig.1).

Regarding the base excess, the $\mathrm{Cg}$ had a reduction 8 hours after fasting and remained low until the end of the experiment. The reduction in the NTg occurred after 4 hours, remaining reduced until the end. For the Tg, reduction occurred only at 8 and 24 hours after fasting (Fig.1).

There was a reduction of bicarbonate in the $\mathrm{Cg}$ animals after four hours of forage ingestion, remaining low until the end of the experiment. In the NTg, the reduction occurred at eight hours after ingestion of the concentrate and remained low until the end. For the Tg the reduction occurred between 16 and 36 hours, returning to zero at 48 hours. The NTg had the lowest values at 16 and 36 hours (Figure 1). No significant changes in $\mathrm{PO}_{2}, \mathrm{PCO}_{2}, \mathrm{SO}_{2}$ were observed.

\section{DISCUSSION}

The model for the induction of ruminal lactic acidosis used in this study aimed to simulate a condition that occurs naturally, secondary to carbohydrate intake after fasting. This model was effective in causing ruminal acidosis, observed through the manifestation of classic acidosis clinical signs, such as reduced food intake, rumination, depression and diarrhea, and in particular by reducing the ruminal $\mathrm{pH}$. The control group used in this study was of fundamental importance, since it demonstrated changes due to fasting, which can aggravate ruminal acidosis, persisting even on the second day after feeding. The increase in ruminal $\mathrm{pH}$ after fasting was observed by Bond et al. (1975) and Galyean et al. (1981), and occurs mainly by the reduction of acid production as well as the increased absorption of these, be-

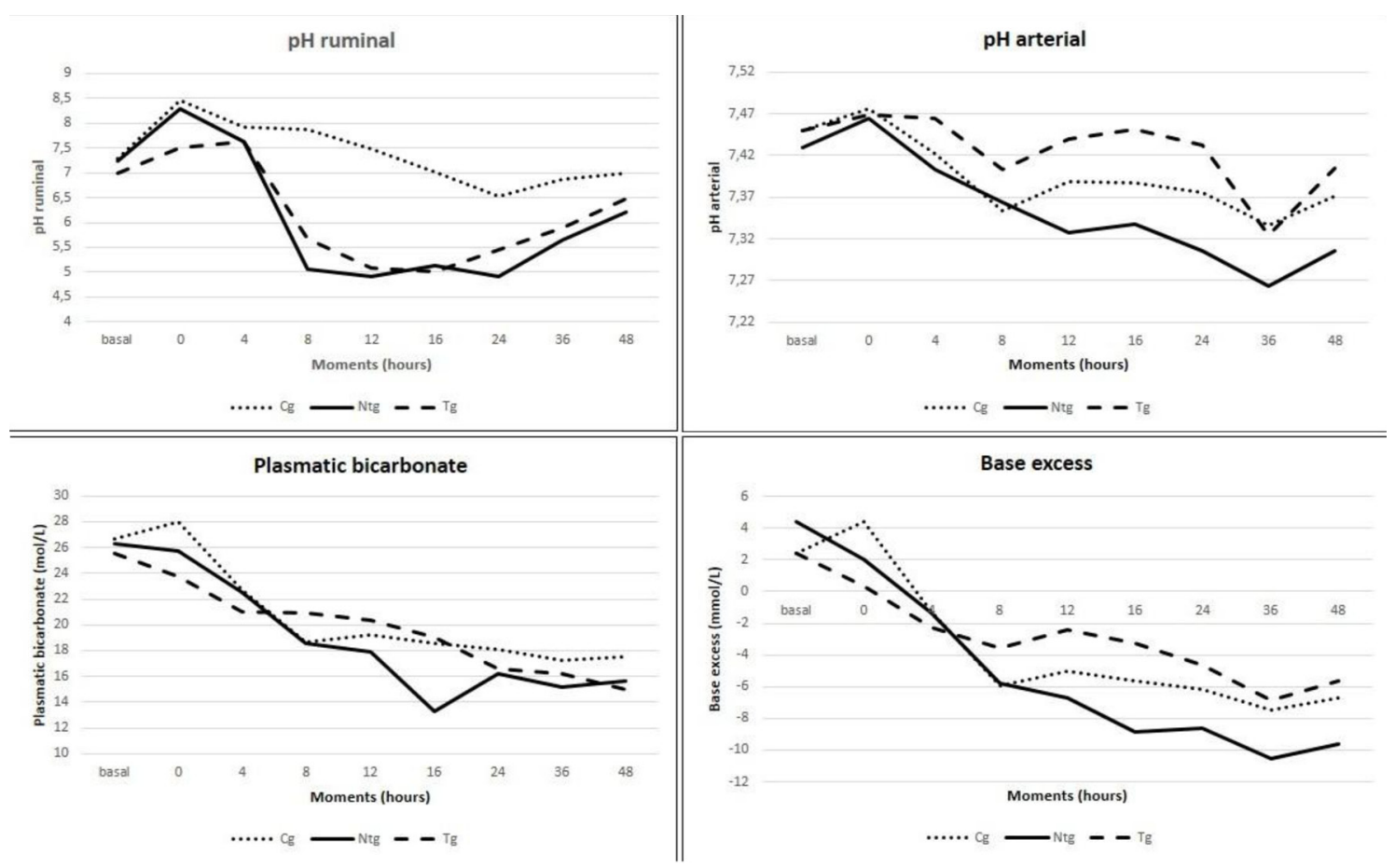

Fig.1. Ruminal pH, arterial pH, base excess and plasmatic bicarbonate of each experimental group and moments. 
sides the constant saliva secretion, which is highly alkaline. However, these studies have not reported the implication of fasting on the systemic condition of the animal, resulting in reduced blood $\mathrm{pH}$, bicarbonate and base excess. According to Dunlop (1972), the absorption of lactic acid occurs most frequently not only in situations of low ruminal $\mathrm{pH}$, but also during the ruminal stasis observed in the absence of food intake, which could explain the metabolic acidosis observed in the control group.

Barreto Júnior et al. (2008) demonstrated that higher concentrations of lactic acid, observed in lactic acidosis caused by sucrose administration in cattle, occur at about nine hours after the induction, associated with more pronounced reduction in ruminal pH. Similarly, in this study, the reductions in ruminal $\mathrm{pH}$ were observed at eight hours in animals of the NTg and Tg groups, remaining reduced until 36 hours. Afonso et al. (2002), using an experimental model with sucrose in sheep, had the lowest ruminal $\mathrm{pH}$ at about 24 hours after the induction, similar to what occurred in this study with the control group subjected to prolonged fasting.

The use of buffers in ruminant feeds is frequent, often using sodium bicarbonate and ionophores, such as monensin and salinomycin. Ortolani et al. (2010) observed an increase in the ruminal $\mathrm{pH}$ in sheep treated with monensin and subjected to ruminal acidosis. However, Miranda Neto et al. (2011), using sheep that underwent rumen lactic acidosis by administration of sucrose, observed that monensin was unable to control the ruminal $\mathrm{pH}$ in the animals, similar to the findings observed in this study, since the bicarbonate was unable to control the reduction of the ruminal pH. Salinomycin was also not effective in the prevention of acidosis by the administration of sucrose in sheep, but it minimized its adverse effects (Camara et al. 2013).

It is suggested that the increase in ruminal $\mathrm{pH}$ after fasting occurs due to continuous absorption of previously produced acids as well as the buffer caused by increased production of saliva. Unlike the Cg and NTg groups, which showed an increase in ruminal $\mathrm{pH}$ after fasting of 48 hours, the $\mathrm{Tg}$ presented no change in the $\mathrm{pH}$ value at this time, contrary to the expected, since the bicarbonate raises the $\mathrm{pH}$ of the solutions. This result may indicate a beneficial effect such as enhanced stability of the rumen content, compared to the reduction of food intake for a period of two days, as may happen in transport situations.

Considering the hemogasometry results, this experimental model produced a reduction of the blood $\mathrm{pH}$ at eight hours after induction of acidosis. Barreto Júnior et al. (2008) observed a reduced blood pH only after 12 hours of acidosis induction with sucrose. In the study of Ortolani et al. (2010), in Gir and Jersey cattle after induction of ruminal lactic acidosis with sucrose, monensin was not able to maintain blood $\mathrm{pH}$ in animals after induction of acidosis. In the present study, the bicarbonate could not control the reduction in ruminal $\mathrm{pH}$, but had a buffering effect on the lactic acid absorbed from the rumen, as the treated animals had the arterial pH decreased only 36 hours after the concentrate intake, and this value was not different from that in the control group. It is suggested that the $\mathrm{pH}$ reduction occurred at this time as a result of the fasting, and not by acidosis per se. Apparently, the effects of monensin and bicarbonate differ, because monensin appears to have a greater role in the prevention of ruminal $\mathrm{pH}$ control, having no effects on the metabolic balance, other than bicarbonate, which acted by preventing metabolic acidosis, despite its little effect on the ruminal pH. Afonso et al. (2002) also observed this result, when the monensin sodium was not able to prevent metabolic acidosis in sheep with ruminal lactic acidosis, secondary to administration of sucrose.

The plasma bicarbonate of the Tg group decreased only three times, at 16, 24 and 36 hours, and it exceeded the value of the NTg at 16 hours, no differing from the Cg at any time. Even subjected to ruminal acidosis, treated animals returned to the plasma bicarbonate zero value at the end of the experiment, suggesting that its use preventively reduced the severity of metabolic acidosis secondary to ruminal acidosis and prolonged fasting.

The base excess (BE) is interpreted as a deviation in the normal bicarbonate concentration, and for an animal with metabolic acidosis it indicates the amount of bicarbonate required to correct the acid-base balance (Patraet al. 1993, Sobiech et al. 2005). It is observed that the Tg presented higher BE values than the NTg at 16 hours, and all groups showed the greatest reduction at 24 hours, when the plasma bicarbonate and arterial $\mathrm{pH}$ also reduced significantly. The result of the Tg differs from the NTg, which decreased its BE at all times after induction of acidosis, and does not differ of the $\mathrm{Cg}$ at any time. Cg animals showed a BE reduction from 8 hours to 48 hours, demonstrating the occurrence of metabolic acidosis because of fasting.

In the study by Afonso et al. (2005), sheep receiving monensin as prevention to ruminal acidosis showed no hemogasometric difference. Moreover, in this study, changes were observed when comparing the different experimental groups, such as elevation of plasma bicarbonate and BE, which indicates more efficient buffer mechanisms with the use of sodium bicarbonate for the blood $\mathrm{pH}$ control and the restoration of the hemodynamic balance. Until now, studies with bicarbonate had not shown efficacy in the prevention of experimentally induced acidosis (Erdman 1988), being used in the treatment of acute (Aslan et al. 1995, Kezar \& Chuch 1979) or subacute illness (Hu \& Murphy 2005). However, this study provides results indicating a beneficial effect of bicarbonate on acid-base imbalances caused by acidosis and by prolonged fasting.

The preventive treatment with sodium bicarbonate was able to attenuate metabolic acidosis secondary to ruminal acidosis and prolonged fasting, elevating the blood $\mathrm{pH}$, plasma bicarbonate and base excess; however, it had no effect on the reduction of the ruminal $\mathrm{pH}$.

Acknowledgements.- This study was fully funded by the Foundation for Research Support of Mato Grosso (Fundação de Amparo à Pesquisa de Mato Grosso - FAPEMAT/MT).

\section{REFERENCES}

Afonso J.A.B., Ciarlini P.C., Kuchembuck M.R.G., Kohayagawa A., Feltrin L.P.Z., PinotiCiarlini L.D.R., Laposy C.B., Mendonça C.L. \& Takahira R.K. 2002. Metabolismo oxidativo dos neutrófilos de ovinos tratados com 
monensina sódica e experimentalmente submetidos à acidose ruminal. Pesq. Vet. Bras. 22(4):129-134.

Afonso J.A.B., Kuchembuck M.R.G., Feltrin L.P.Z., Laposy C.B., Kohayagawa A., Mendonça C.L. \& Takahira R.K. 2005. Avaliação do uso da monensina sódica na prevenção da acidose láctica ruminal experimental em ovinos. Vet. Noticias 11:(1)35-43.

Aschenbach J.R. \& Gabel G. 2000. Effect and absorption of histamine in sheep rumen: significance of acidotic epithelial damage. J. Anim. Sci. 78:464-470.

Aslan V., Thamsborg S.M., Jorgensen R.J. \& Basse A. 1995. Induced acute ruminal acidosis in goats treated with yeast (Saccharomyces cerevisiae) and bicarbonate. Acta Vet. Scand. 36(1):65-77.

Barreto Júnior R.A., Minervino A.H.H., Rodrigues F.A.M.L., Antonelli A.A., Sucupira M.C.A., Mori C.S. \& Ortolani E.L. 2008. Avaliação do potencial da polpa cítrica em provocar acidose láctica ruminal aguda em bovinos. Braz. J. Vet. Res. Anim. 45(6):421-428.

Bond J., Rumsey T.S. \& Weinland B.T. 1975. Effect of deprivation and reintroduction of feed and water on the feed and water intake behavior of beef cattle. J. Anim. Sci. 41:392.

Braun U., Rihs T. \& Schefer U. 1992. Ruminal lactic acidosis in sheep and goats. Vet. Rec. 130(16):343-349.

Camara A., Afonso J.A.B., Mendonça C.L. \& Vieira A.C.S 2013. Efeito da salinomicina na prevenção da acidose láctica ruminal experimental em ovinos. Ciênc. Anim. Bras. 14(1):65-73.

Cottee G., Kyriazakis I., Widowski T.M., Lindinger M.I., Cant J.P., Duffield T.F., Osborne V.R. \& McBride B.W. 2004. The effects of subacute ruminal acidosis on sodium bicarbonate-supplemented water intake for lactating dairy cows. J. Dairy Sci. 87(7):2248-2253.

Dunlop R.H. 1972. Pathogenesis of ruminant lactic acidosis. Adv. Vet. Sci. Comp. Med. 16:259-302.

Erdman R.A. 1988. Dietary buffering requirements of the lactating dairy cow: a review. J. Dairy Sci. 71:3246-3266.

Galyean M.L., Lee R.W. \& Hubbert M.E. 1981. Influence of fasting and transit on ruminal and blood metabolites in beef steers. J. Anim. Sci. 53(1):7-18.

Golder H.M., Celi P., Rabiee A.R. \& Lean I.J. 2014. Effects of feed addtives on rumen and blood profiles during a starch and fructose challenge. J. Dairy Sci. 97(2):985-1004.

Ha J.K., Emerick R.J. \& Embry L.B. 1983. In vitro effect of $\mathrm{pH}$ variations on rumen fermentation, and in vivo effects of buffers in lambs before and after adaptation to high concentrate diets. J. Anim. Sci. 56:698-706.

Hu W. \& Murphy M.R. 2005. Statistical evaluation of early- and mid-lactation dairy cow responses to dietary sodium bicarbonate addition. Anim. Feed Sci. Technol. 119:43-54.
Kezar W.W. \& Church D.C. 1979. Effect of thiopeptin and sodium bicarbonate on the prevention of lactic acidosis induced in sheep. J. Anim. Sci. 49:1396-1402.

Kohn R.A. \& Dunlop T.F. 1998. Calculation of the buffering capacity of bicarbonate in the rumen and in vitro. J. Anim. Sci. 76:1702-1709.

Lahiri S., Edelman N.H., Cherniack N.S. \& Fishman A.P. 1981. Role of carotid chemoreflex in respiratory acclimatization to hypoxemia in goat and sheep. Respir. Physiol. 46:367-382.

Miranda Neto E.G., Afonso J.A.B., Mendonça C.L. \& Almeida M.Z.P.R.B. 2005. Estudo clínico e características do suco ruminal de caprinos com acidose láctica induzida experimentalmente. Pesq. Vet. Bras. 25(2):73-78.

Miranda Neto E.G., Silva S.T.G., Mendonça C.L., Drummond A.R.F. \& Afonso J.A.B. 2011. Aspectos clínicos e a bioquímica ruminal de caprinos submetidos à acidose láctica experimental e suplementados ou não com monensina sódica. Pesq. Vet. Bras. 31(5):416-424.

Nagaraja T.G. \& Taylor M.B. 1987. Susceptibility and resistance of ruminal bacteria to antimicrobial feed aditives. Appl. Environ. Microbiol. 53:1620-1625.

Oliveira D.M., Medeiros J.M.A., Assis A.C.O., Neves A.B., Galiza G.J.N., Simões S.V.D., Dantas A.F.M. \& Riet-Correa F. 2009. Acidose láctica ruminal aguda em caprinos. Ciênc. Anim. Bras., p.117-122. Disponível em <http:// www.revistas.ufg.br/index.php/vet/article/view/7735/5504> Acesso em 15 Jul. 2014.

Ortolani E.L. 2003. Diagnóstico e tratamento de alterações ácido-básicas em ruminantes, p.17-29. In: Gonzalez F.H.D., \& Campos R. (Eds), Anais do Primeiro Simpósio em Patologia Clínica Veterinária da Região Sul do Brasil. UFRGS, Porto Alegre.

Ortolani E.L., Maruta C.A. \& Minervino A.H.H. 2010. Aspectos clínicos da indução da acidose láctica ruminal em zebuínos e taurinos. Braz. J. Vet. Res. Anim. Sci. 47(4):253-261.

Patra R.C., Lal S.B. \& Swarup D. 1993. Physicochemical alterations in blood, cerebrospinal fluid and urine in experimental lactic acidosis in sheep. Res. Vet. Sci. 54(2):217-220.

Phy T.S. \& Provenza F.D. 1998. Sheep fed grain prefer foods and solutions that attenuate acidosis. J. Anim. Sci. 76:954-960.

Reichert Neto N.C. 1996. Fistulação ruminal em ovinos, In: Anais Congresso Pan-Americano de Ciências Veterinárias, Campo Grande, MS. Cia. Brasileira de Comunicação, Campo Grande, MS. 127p.

Slyter L.L. 1976. Influence of acidosis on rumen function. J. Anim. Sci. 43:910-929.

Sobiech P., Stopyra A., Kuleta Z., Zbanyszek M. \& Milewki S. 2005. Acid-base balance parameters of arterial, venous and capillary blood in sheep. Bull. Vet. Inst. Pulawy 49:125-127. 